\title{
Hydroquinone degradation via reductive dehydroxylation of gentisyl-CoA by a strictly anaerobic fermenting bacterium
}

\author{
Norbert Gorny, Bernhard Schink \\ Fakultät für Biologie, Universität Konstanz, Postfach 5560, D-78434 Konstanz, Germany \\ Recelved: 10 May 1993/Accepted: 8 July 1993
}

\begin{abstract}
Anaerobic degradation of hydroquinone was studied with the fermenting bacterium strain HQGö1. The rate of hydroquinone degradation by dense cell suspensions was dramatically accelerated by addition of $\mathrm{NaHCO}_{3}$. During fermentation of hydroquinone in the presence of ${ }^{14} \mathrm{C}-\mathrm{Na}_{2} \mathrm{CO}_{3}$ benzoate was formed as a labelled product, indicating an initial ortho-carboxylation of hydroquinone to gentisate. Gentisate was activated to the corresponding CoA-ester in a CoA ligase reaction at a specific activity of $0.15 \mu \mathrm{mol} \times \mathrm{min}^{-1} \times \mathrm{mg}$ protein $^{-1}$. Gentisyl-CoA was reduced to benzoyl-CoA with reduced methyl viologen as electron donor by simultaneous reductive elimination of both the ortho and meta hydroxyl group. The specific activity of this novel gentisyl-CoA reductase was $17 \mathrm{nmol} \times \mathrm{min}^{-1} \times \mathrm{mg}$ protcin ${ }^{-1}$. Further degradation to acetate was catalyzed by enzymes which occur also in other bacteria degrading aromatic compounds via benzoyl-CoA.
\end{abstract}

Key words: Anaerobic degradation - Aromatic compounds - Gentisate - Carboxylation - Reductive elimination - Benzoyl-CoA pathway

Many phenolic compounds of simple or complex structure are synthesized in the secondary metabolism of higher plants. Because of their surface active properties and membrane-destabilizing effect the majority of non-polymeric phenols are found as glycoside derivatives. This is also true for hydroquinone, the most widely distributed representative of simple phenols which is transformed in a reaction with uridine diphosphate glucose to the glycoside arbutin (Conn 1964). In contrast to other hydroxy aromatics, hydroquinone and its carboxyl derivative gentisic acid occur also as free compounds in many plant tissues (Pridham 1965).

Anaerobic degradation of aromatics proceeds generally through reductive destabilization of the aromatic $\pi$-electron structure, but only few compounds are known

Correspondence to. B. Schink to be subject to direct ring reduction. Most of them have to be transformed first into one of three central intermediates. Many novel enzyme activities catalyzing carboxylations, reductive eliminations, oxidations, and $\mathrm{CoA}$ activations have becn found to be involved in such modifications of a broad variety of mononuclear aromatics (Evans and Fuchs 1988; Schink et al. 1992). For phenolic compounds, two different strategies are known: (i) Resorcinol and phloroglucinol degradation proceeds through direct reduction and subsequent hydrolytic cleavage of the aromatic ring (Kluge et al. 1990; Brune and Schink 1992). (ii) Carboxylation, CoA-activation, and reductive dehydroxylation are the key reactions in anaerobic phenol degradation via benzoyl-CoA (Lack et al. 1991; Gallert et al. 1991).

Since the hydroxyl groups of hydroquinone are in para position to each other, direct hydrolytic cleavage of the aromatic ring seems to be unlikely. Also reductive elimination of one of the hydroxyl groups to form phenol as an internediate is improbable since dehydroxylation has been demonstrated so far only for coenzyme A-linked aromatic compounds. Carboxylation of hydroquinone to gentisate as the first reaction in anaerobic degradation has been proposed earlier for the fermenting bacterium strain HQGö1 (Szewzyk and Schink 1989). This bacterium degrades bydroquinone to benzoate and acetate in pure culture, and oxidizes hydroquinone, gentisate, and benzoate to acetate and $\mathrm{CO}_{2}$ in the presence of a methanogenic partner bacterium. A sulfate-reducing bacterium able to grow with hydroquinone and gentisate has been described as well (Schnell et al. 1989). So far, nothing is known about the enzymes catalyzing the anaerobic degradation of hydroquinone.

In the present communication we report on new results obtained with strain HQGö1 which allow us to propose a pathway for anaerobic hydroquinone degradation.

\section{Materials and methods \\ Media and growth conditions}

$\Lambda$ bicarbonate-buffered. sulfide-reduced mineral medium essentially as described earlier (Widdel and Pfeunig 1981: Schink and Pfennig 
1982) was used which contained a 7 vitamm solution (Widdel and Pfennig 1981), trace clement solution SI. 10 (Widdel et al. 1983) and selenite-tungstate solution (Tschech and Pfennig 1984). Hydroquinone and gentisate were stored as stock solutions in sterile infusion bottles under nitrogen gas, and were added to cultures wath syringes. Strain HQGö1 was grown in $500 \mathrm{ml}$ screw cap bottles or in 1-l infusion bottles with $1-3 \mathrm{mM}$ aromatic substrate under a $\mathrm{N}_{2} / \mathrm{CO}_{2}$ atmosphere at $28^{\circ} \mathrm{C}$. Growth was recorded by measuring OD at $578 \mathrm{~nm}$ wavelength.

\section{Experiments with dense cell suspensions}

Cells were harvested in the late logarithmic phase of growth $\left.(O)_{578}=0.25-0.27\right)$ under anoxic conditions in a Sorvall RC-5B centrifuge (Du Pont de Nemours, Bad Hombutg. Germany) at $9000 \times \mathrm{g}$ for $30 \mathrm{~min}$ at $4{ }^{\circ} \mathrm{C}$. Manipulations were carried out in an anoxic chamber (Coy, Ann Arbor, Mich.. USA) under $\mathrm{N}_{2} / \mathrm{H}_{2}(95: 5)$. Gas-tight centrifuge bottles were incubated in the chamber for at least $24 \mathrm{~h}$ before use. After centrifugation pellets were washed in potassium phosphate of $50 \mathrm{mM}$ MOPS/KOH buffer, $\mathrm{pH} 7.0$, supplemented with $2 \mathrm{mM}$ DTE and $5 \mathrm{mM} \mathrm{MgCl}_{2}$, and suspended in the same buffer after a further centrifugation step. The cell density was adjustcd to $\mathrm{OD}_{57 \mathrm{~mm}}=10$. Experiments with cell suspensions were performed anoxically in $5 \mathrm{ml}$ rubber-sealed Hungate tubes under $\mathrm{N}_{2}$ or $\mathrm{N}_{2} / \mathrm{CO}_{2}(90: 10)$. Samples were taken with syringes and diluted immediately in $0.1 \mathrm{M} \mathrm{H}_{3} \mathrm{PO}_{4}$.

Incorporation of ${ }^{14} \mathrm{CO}_{2}$ was tested with cell suspensions, 100. The assay mixture contained $100 \mathrm{mM}$ potassium phosphate buffer, $\mathrm{pH} 7.0,2.75 \mathrm{mM}$ hydroquinone or gentisate, $2 \mathrm{mM}$ DTE, $20 \mathrm{mM}$ $\mathrm{NaHCO}, 10 \mathrm{mM} \mathrm{MgCl}$, and $0.5 \mathrm{mM} \mathrm{MnCl}$. Experiments were started by injecting $\mathrm{Na}_{2}{ }^{14} \mathrm{CO}_{3}\left(150 \mathrm{kBq} \times \mathrm{ml}^{-1}\right.$, specific radioactivity $7.5 \mathrm{kBq} \times$ umol $^{-1}$ ). Samples were taken wilh syringes and handled as described (Tschech and Fuchs 1989).

\section{Preparation of cell extracts}

Cell cxtracts were prepared anoxically by french pressure cell treaiment at $138 \mathrm{MPa}$ of fresh cells harvested as decribed above, or from frozen cells which were stored in liquid nitrogen. Alternatively, crude extract was obtained by lysozyme treatment $(15 \mathrm{mg}$ lysozyme per g dry cell matter plus $10 \mathrm{mM}$ EDTA) for 30 min at $25^{\circ} \mathrm{C}$. Cell debris was removed by centrifugation at $15000 \times \mathrm{g}$ for 30 min at $4{ }^{\circ} \mathrm{C}$. Membranes were separated from cytoplasm by centrifugation al $420000 \times \mathrm{g}$ for $30 \mathrm{~min}$ in an Optima TL ultracentrifuge (Beckman, Munich, Germany) and resuspended in buffer. All steps were carried out in reduced buffers ( $2 \mathrm{mM}$ DTE) appropriate for the respective enzyme assay.

\section{Enzyme assays}

Enzyme assays were carricd out under anoxic conditions at $25^{\circ} \mathrm{C}$ either in tests discontinuously analyzed by high pressure liquid chromatography (HPLC), or in continuous photometric assays. The crude extract used for the assays was freshly prepared or stored in liquid nitrogen no longer than 3 days.

Acyl-CoA synihetase was assayed as described carlier (Schncll and Schink 1991). The assay mixture contained $50 \mathrm{mM}$ potassium phosphate buffer, $\mathrm{pH} 7.0$, with $0.5 \mathrm{mM} \mathrm{CoASH}, 0.5-1 \mathrm{mM}$ substrate, $10 \mathrm{mM} \mathrm{MgCl}_{2}$ and $1-2 \mathrm{mM} \triangle \mathrm{IP}$. In addition, a photometric assay was performed measuring the AMP formed in the CoA ligase raaction by a coupled enzyme assay (Geissier et al. 1988).

Carboxylation of hydroquinone was tested following the exchange of ${ }^{14} \mathrm{C}$ of $\left[{ }^{14} \mathrm{C}\right]$-carbonate into the carboxyl group of gentisate or other aromatic acids in a discontinuous dssay (Tschech and Fuchs 1989).

Enzymes catalyzing a reductive dehydroxylation of aromatic CoA-esters were assayed discontinuously by quantification of both substrate and product by HPLC. Tests were performed in $100 \mathrm{mM}$ potassium phosphate or $50 \mathrm{mM}$ HEPES buffer, $\mathrm{pH} 7.0$, with $2 \mathrm{mM}$ DTE, $5 \mathrm{mM} \mathrm{MgCl}_{2}$, and $0.1-1 \mathrm{mM}$ of elcctron donor. In some cases, reduced viologens were prepared with $10 \mathrm{mM}$ formate as electron donor using the formate dehydrogenase present in the cell extract. Reduction of 2-hydroxybenzoyl-CoA and 3-hydroxybenzoyl-Co $\Lambda$ was tested by adding $0.5 \mathrm{mM}$ substrate to a test buffer with a suitable electron donor. Gentisyl-CoA reductıon was assayed in a combined assay including the CoA tigase reaction to generate gentisyl-CoA, or by adding purified, enzymatically synthetisized gentisyl-CoA to the assay mixture. In addition, gentisyl-CoA reductase was measurcel photometrically following the axidation of reduced benzyl viologen $(0.15 \mathrm{mM})$ at $578 \mathrm{~nm}$. The assay mixture contained $0.3 \mathrm{mM}$ gentisyl-CoA, and was started by adding either cell extract or substrate. The reaction products were analyzed by HPLC.

Benzay-CoA : acceptor CoA transferase was tested with benzoylCoA $(0.5-2.5 \mathrm{mM})$ as CoA-donor and gentisate or acetate (each $0.5-10 \mathrm{mM}$ ) as acceptor in $50 \mathrm{mM}$ potassium phosphate buffer, $\mathrm{pH} 7.0$, with $2 \mathrm{mM}$ DTE, Changes in the concentrations of $\mathrm{COA}$ esters were quantified by HPLC.

Glutaryl-CoA dehydrogenase (EC 1.3.99.7) was assayed after Stams et al. (1984). The assay mixture contained $50 \mathrm{mM}$ potassium phosphate buffer, $\mathrm{pH} 7.2,2 \mathrm{mM}$ DTF, $1 \mathrm{mM} \mathrm{\textrm {K } _ { 3 }} \mathbf{F e}(\mathbf{C N})_{6}$ $\left(\varepsilon_{420}=0.9 \mathrm{mM}^{-1} \times \mathrm{cm}^{-1}\right), 0.1 \mathrm{mM}$ phenazine-methosulfate, and $0.5 \mathrm{mM}$ glutaryl-CoA.

Giutacony-CoA decarboxylase (EC 4.1.1.70) was assayed after Buckel (1986). The assay mixture contained $100 \mathrm{mM}$ Tris-HCL, $\mathrm{pH}$ 7.5, $2 \mathrm{mM}$ DTE, $0.2 \mathrm{mM} \mathrm{Co \Lambda ,} 0.1 \mathrm{mM}$ acetyl phosphate, and $1 \mathrm{mM}$ $\mathrm{N} \Lambda \mathrm{D}$. Auxiliary enzymes from Acidaminococcus fermentans were provided by Prof. Dr. W. Buckel, Marburg, Germany (Buckel 1986). The reaction was followed at $365 \mathrm{~nm}$ upon addition of $1 \mathrm{mM}$ glutaconate.

Crotonase (EC 4.2.1.17) was measured following the decrease of crotonyl-CoA at $263 \mathrm{~mm}$ (Moskowitz and Merrick 1969).

3-Hydroxybutyryi-CoA dehydrogenase (EC 1.1.1.157) was measured following NADH oxidation at $365 \mathrm{~nm}$. The assay nuxture contained $100 \mathrm{mM}$ potassium phosphate buffer $\mathrm{pH} 7.0,0.3 \mathrm{mM}$ acetoacetyl-CoA, and $0.3 \mathrm{mM}$ NADH (Bergmeycr 1983).

$\beta$-Ketothiolese (EC 2.3.1.16) was measured by a standard method (Lynen and Ochoa 1953; Stern 1956).

Phosphotransacetylase (EC 2.3.1.8) and acetate kinase (EC 2.7.2.1) were assayed after Bergmeyer (1983). Benzoate kinase was measured the same way, with $100 \mathrm{mM}$ benzoate as substrate.

Curbon monoxide dehydrogenase (EC 1.2.99.2) was measured recording benzy] viologen reduction upon addition of carbon monoxide at $578 \mathrm{~nm}$ (Dickert and Thauer 1978). Hydrogenase (EC 1.18.99.1) and formate dehydrogenuse (EC 1.2.1.2) were assayed in the same way with hydrogen or $10 \mathrm{mM}$ formate as electron donor

Protein was quantified as described by Bradford (1976), with bovine sertm albumin as standard.

\section{Analytical methods}

Aromatic compounds, CoASH, CoA esters, ATP, ADP, and AMP were analyzed and quantified by HPLC (Brune und Schink 1990). Separation was performed with an Ultrasphere-ODS column $(4.6 \times 150 \mathrm{~mm}$, Beckman Instruments, München, Germany) and gradients or mixtures of $100 \mathrm{mM}$ ammonium phosphate buffer $(\mathrm{pH}$ 2.6 and methanol as the mobile phase. Peaks were analyzed by a computer program (System Gold, Beckman Instruments) and quantified by comparison with internal and external standards. Aromatic CoA esters were identified through their retention tines and UV spectra at various $\mathrm{pH}$ values $(2.5,7$ and 11$)$ after separation by HPLC (Webster et al. 1974).

${ }^{14} \mathrm{C}$-Benzoate was analyzed by IFPLC, too. In addition to the $U V$ detector, a RAMONA-5 radioactivity HPIC monitor andiyzer (Raytest. Straubenhardt, Germany) was used. Detection of radioactivity was performed with a glass scintsllator flow cell (net volume $400 \mu 1)$ and $1 .{ }^{14} \mathrm{C}$-benzoate as slandard. 
Acctate and hydrogen were analyzed by gas chromatography (Platen and Schink 1989).

\section{Chemicals}

2-Hydroxybenzoyl-CoA, 3-hydroxybenzoyl-CoA, and gentisyl-CoA were synthesized from CoASH and the corresponding anhydrides (Simon and Shemin 1953; Merkel at al 1989). In addition, gentisyl-CoA was prepared cnzymatically using crude cell extract of strain HQGöl in a CoA ligase rcaction by incubation for 30 min. The reaction was stopped by centrifugation al $3000 \times \mathrm{g}$ in a centriprep concentrator (Amicon, Witten, Germany) for $60 \mathrm{~min}$. The filtrate contained $0.3-0.45 \mathrm{mM}$ gentisyl-CoA which was purified by HPLC.

All other chemicals were obtaned from Alfa products, Karlsruhe, Germasy: Boehrınger, Mannheim, Germany; Fluka, Neu-Ulm, Germany; Merck, Darmstadt, Germany; Serva, Heidelberg, Germany; and Sigma, Deisenhofen, Germany.

\section{Results}

Dependence of hydroquinone fermentation on $\mathrm{CO}_{2}$

Strain HQGöl converted hydroquinone to acetate and benzoate without significant production of hydrogen. During this fermentation a phenolic compound is converted to an aromatic acid, which requires carboxylation and reduction of the substrate molecule. The influence of sodium bicarbonate $(50 \mathrm{mM})$ on the rate of hydroquinone and gentisate degradation was tested in experiments with dense cell suspensions. The degradation
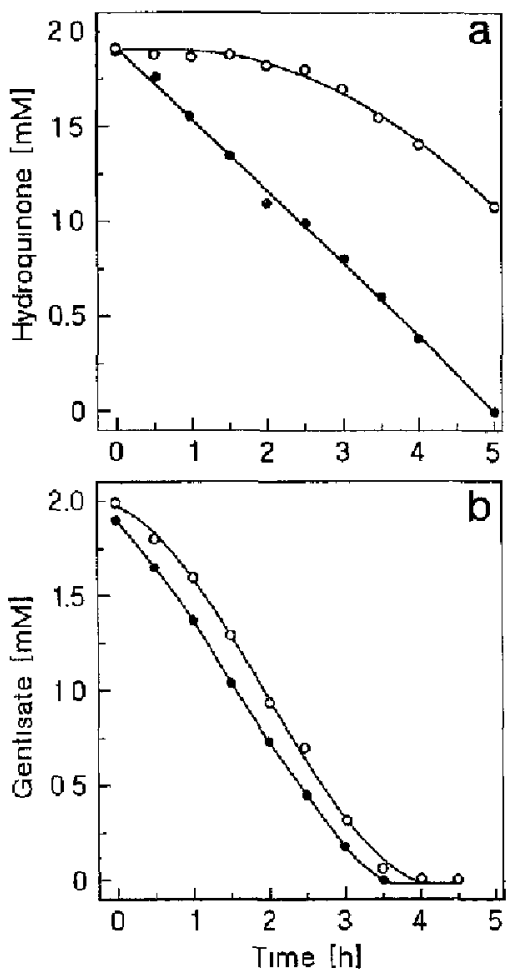

Fig. 1. Degradation of $\mathbf{a}$ hydroquinone and $\mathbf{b}$ gentisate by dense cell suspensions in the absence of $\mathrm{CO}_{2}(\mathrm{O})$ and with the addition of $50 \mathrm{mMINaHCO}$ (-) rate of the carboxylated derivative gentisate was exactly the same in the presence or absence of bicarbonate. In contrast, the hydroquinone concentration in bicarbonatefree assays did not decrease at all for more than $2 \mathrm{~h}$, and thereafter did so only slowly. In the presence of bicarbonate, degradation followed linear kinetics (Fig. 1a, b).

\section{Fixation of ${ }^{14} \mathrm{CO}_{3}$ in fermemtation products}

Hydroquinone and gentisate (each $2.75 \mathrm{mM}$ ) were fermented by dense cell suspensions to form up to $0.9 \mathrm{mM}$ benzoate with either substrate. During fermentation in the presence of $\left[{ }^{14} \mathrm{C}\right]-\mathrm{Na}_{2} \mathrm{CO}_{3}$ formation of benzoate and increase of ${ }^{14} \mathrm{C}$-label in the fermentation products were monitored by HPLC. Unfortunately, the preparation procedure stripped acid-volatile products from the reaction mixture, and therefore acetate as a further labelled product could not be quantified. With hydroquinone $(2.75 \mathrm{mM})$ as substrate, the ${ }^{14} \mathrm{C}$-label in benzoate increased parallel to benzoate formation (Fig. 2a). Since the specilic radioactivity was $7.5 \mathrm{kBq}$ per $\mu \mathrm{mol}$ of total available $\mathrm{CO}_{2}$ from $\mathrm{HCO}_{3}^{-}, 6.75 \mathrm{kBq}$ was expected in the $0.9 \mathrm{mM}$ benzoate formed. We measured $6.95 \mathrm{kBq}$. Incorporation of ${ }^{14} \mathrm{C}$-label into benzoate was much lower with gentisate as substrate but a low time-linear ${ }^{14} \mathrm{C}$ incorporation was observed as well (Fig. 2b).

In assays with crude extracts of hydroquinone-grown cells, a carboxylating enzyme could not be detected, neither by HPLC measurement of reaction products nor by measuring ${ }^{14} \mathrm{C}$ incorporation into acid-stable products

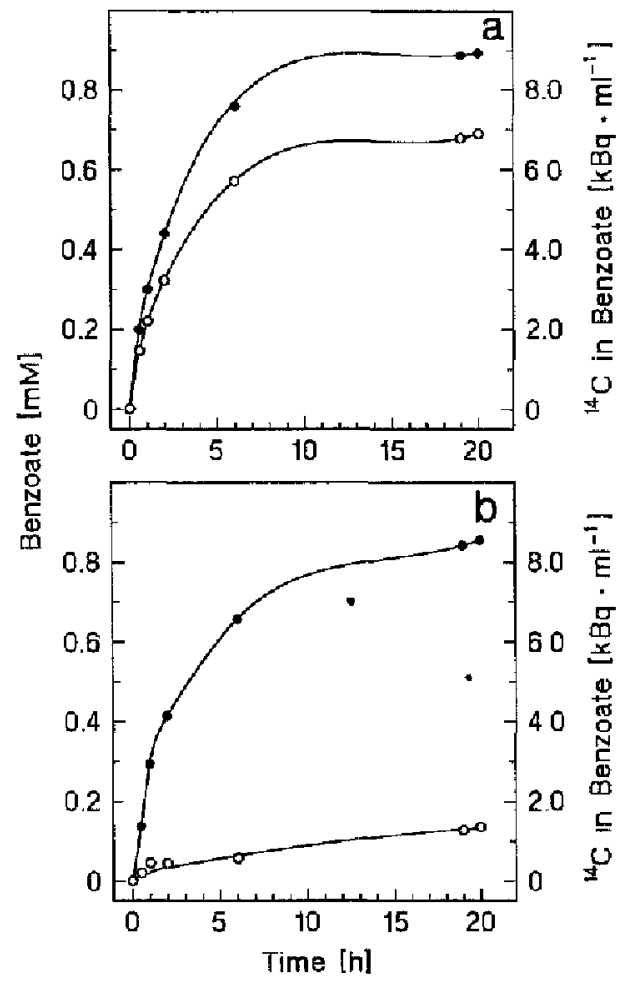

Fig. 2. Formalion of ${ }^{14} \mathrm{C}$-benzoate during fermentation of a hydroquinone and b gentisate by coll suspensions of strain HQGöl. Symbols: ( benzoate, (c) ${ }^{14} \mathrm{C}$ label in benzoate 
from hydroquinone and $\left[{ }^{14} \mathrm{C}\right]-\mathrm{Na}_{2} \mathrm{CO}_{3}$. Cofactors such as biotin, thiamin pyrophosphate, pyridoxal phosphate, pyridoxamine hydrochloride, pyridoxal hydrochloride, or vitamin $\mathrm{B}_{6}(50-100 \mu \mathrm{M}$ each) had no effect. No measurable exchange between the carboxyl group of gentisate and ${ }^{14} \mathrm{CO}_{2}$ was catalyzed by cell-free extract either. The protein concentration in these experiments was $0.1-2.5 \mathrm{mg} \times \mathrm{ml}^{-1}$.

\section{Acyl-CoA ligase activity}

Several aromatic acids were activated to the corresponding CoA-esters by extracts of hydroquinone-grown cells of strain HQGö1. Gentisate was converted to gentisyl-CoA in a reaction which was linear with time only during the first 3-4 min. Besides gentisate, also benzoate was activated at high specific activities (Table 1 ). In contrast, salicylate and 3-hydroxybenzoate were converted only with comparably low activity. AMP rather than ADP was formed from ATP. After ATP or CoASH in the assay mixture was used up the concentration of the product decreased at a rate of $0.07 \mu \mathrm{mol} \times \mathrm{min}^{-1} \times \mathrm{mg}$ protein ${ }^{-1}$.

The acyl-CoA ligase was the only enzyme forming gentisyl-CoA. No evidence of a CoA transferase using either acetyl-CoA or benzoyl-CoA as CoA-donor was found.

\section{Reduction of gentisyl-CoA}

Reduction of gentisyl-CoA, salicylyl-CoA, or 3-hydroxybenzoyl-CoA by cell extract of strain HQGöl was studied. Only gentisyl-CoA was found to be subject to reductive dehydroxylation. A time course of a discontinuous assay is shown in Fig. 3. Decrease of gentisyl-CoA started immediately upon addition of the electron donor, with a corresponding nearby stoichiometric increase in benzoyl-CoA concentration. No other aromatic CoA-ester could be detected during the reaction indicating that both hydroxyl groups were removed in one single step. Besides benzoyl viologen and methyl viologen no other electron donor tested proved suitable (Table 2). The highest specific activity was $17 \mathrm{nmol} \times \mathrm{min}^{-1} \times \mathrm{mg}$ protein ${ }^{-1}$ measured with reduced methyl viologen as clectron donor.

The gentisyl-CoA reductase activity was sensitive to oxygen. After treatment with a weak air stream for two

Table 1. Specific activities of acyl-CoA synthetase with several aromatic substrates detected in crude cell extracts of strain HQGö1 grown with hydroquinone

\begin{tabular}{lc}
\hline Substrate & $\begin{array}{l}\text { Spcoific activity } \\
{\left[\text { nmol } \times \text { min }^{-1} \times \text { mg protein }^{-1}\right]}\end{array}$ \\
\hline Benzoate & $174-177$ \\
2-IIydroxybenzoatc & $9.4 \quad 12.3$ \\
3-Irydroxybenzoatc & $16 \quad 19.6$ \\
4-Iydroxybenzoatc & $<0.1$ \\
Gentisate & $150-166$ \\
\hline
\end{tabular}

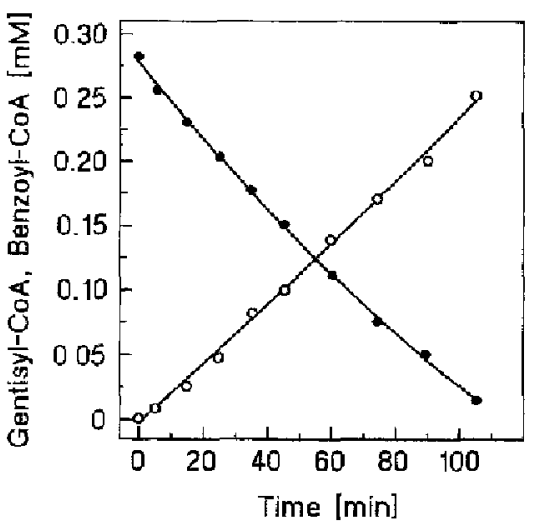

Fig. 3. Reductive dehydroxylation of gentisyl-CoA ( ) to benzoylCoA (O) with reduced methyl viologen as electron donor $(0.15 \mathrm{mg}$ protein $\times \mathrm{ml}^{-1}$ )

Table 2 Specific activity of gentisyl-CoA reductase with various electron donors in cell-free extracts of strain HQGö1 grown with hydroquinone

\begin{tabular}{|c|c|}
\hline Elcetron donor & $\begin{array}{l}\text { Specilic activily } \\
{\left[\text { nmol } \times \min ^{-1} \times \mathrm{mg}^{-1} \text { protein }^{-1}\right]}\end{array}$ \\
\hline Methyl viologen & $9.6-17.2$ \\
\hline Benzyl viologen & $6.6 \quad 9.9$ \\
\hline $\mathrm{Ti}(\mathrm{III})$ citrate & $1-2$ \\
\hline $\mathrm{NADH} / \mathrm{H}^{+}$or $\mathrm{NADPH} / \mathrm{H}^{-}$ & $<0.1$ \\
\hline (Clostridium pasteurianum) & $<0.1$ \\
\hline
\end{tabular}

a Reduced by addition of clithionite

minutes only $10-15 \%$ of the initial activity remained. Activity could not be restored by addition of a reductant.

The localization of gentisyl-CoA reductase was determined with fractionated crude cell extracts prepared by lysozyme/EDTA treatment. 3-Hydroxybutyryl-CoA reductase and hydrogenase were used as marker enzymes for the soluble and membrane fractions, respectively. 3-Hydroxybutyryl-CoA dehydrogenase activity was secovered almost entirely in the soluble fraction whereas $24 \%$ of total hydrogenase activity was found to be membrane-bound. Twelve percent of the gentisyl-CoA reductase activity detected in crude extracts was measured in the membrane fraction while some $30 \%$ of the activity was lost during the fractionation process.

\section{Enzymes of anaerobic benzoate degradation, $\beta$-oxidation,} and $A T P$ formation

Cell extracts of hydroquinone-grown cells catalyzed all reactions necessary for acctate formation from glutarylCoA (Table 3). Glutaryl-CoA dehydrogenase activity and glutaconyl-CoA decarboxylase activity were present as well as cnzymes for $\beta$-oxidation of fatty acids. In contrast to the high activities detected for these enzymes, phosphotransacetylase and acetate kinase could be detected only at very low activities. No enzyme forming 
Table 3. Enzyme activities in extracts of hydroquinone-grown cells of strain HQGö1

\begin{tabular}{|c|c|}
\hline Enzyme & $\begin{array}{l}\text { Specific activitiy } \\
{\left[\text { nmol } \times \mathrm{min}^{-1} \times \mathrm{mg} \text { protein }\right.} \\
\end{array}$ \\
\hline $\begin{array}{l}\text { Glutaryl-CoA dehydrogenase } \\
\text { Glutaconyl-CoA decarboxylase }\end{array}$ & $\begin{array}{c}142-165 \\
55-59\end{array}$ \\
\hline $\begin{array}{l}\text { Crotonase } \\
\text { 3-Hydroxybutyryl-CoA } \\
\text { dehydrogenase } \\
\text { B-Ketothiolase }\end{array}$ & $\begin{array}{c}12660 \cdots 13300 \\
5450-5510 \\
5110-5190\end{array}$ \\
\hline $\begin{array}{l}\text { Phosphotransacetylase } \\
\text { Acetate kinase }\end{array}$ & $\begin{array}{l}45-60 \\
12-20\end{array}$ \\
\hline $\begin{array}{l}\text { Formate dehydrogenase (BV) } \\
\text { Hydrogenase (BV) } \\
\text { CO dehydrogenase (BV) }\end{array}$ & $\begin{array}{c}1450-1500 \\
375-466 \\
0\end{array}$ \\
\hline
\end{tabular}

benzoate from benzoyl-CoA was detectable. No benzoylCoA: acetate CoA transferase, benzoyl-CoA-gentisate: $\mathrm{CoA}$ transferase, or benzoate kinase activity was found.

\section{Discussion}

The phenolic non-carboxylated compound hydroquinone was fermented to acetate and to the non-hydroxylated aromatic acid benzoate by the fermenting bacterium strain HQGō1. Two modification reactions had to take place at the aromatic ring, therefore: (i) carboxylation, and (ii) reductive dehydroxylation.

The first step in anaerobic hydroquinone degradation appears to be a carboxylation in ortho position to one hydroxyl group. The only possible product of this reaction is gentisate. Experiments with resting cells indicated that hydroquinone degradation was significantly accelerated by addition of bicarbonate. Degradation of the carboxyl derivative gentisate was not influenced by the bicarbonate addition. Further evidence of a carboxylation reaction was obtained by following the incorporation of radioactively labelled $\mathrm{CO}_{2} \cdot{ }^{14} \mathrm{C}$ Labelled benzoate was produced in nearby stoichiometric amounts only during hydroquinone fermentation. Incorporation of radioactive label into benzoate was much slower during gentisate degradation indicating an isotope exchange by the carboxylating enzyme (Tschech and
Fuchs 1989). Therefore, fixation of $\mathrm{CO}_{2}$ occurred as at consequence of hydroquinone carboxylation to gentisate.

Since the carboxylation of hydroquinone is an endergonic process (Table 4, (3)) it was not surprising that the cell yield $Y_{\mathrm{s}}\left[\mathrm{g} \mathrm{mol}^{-1}\right]$ of strain HQGöl was $3.6 \mathrm{~g}$ $\mathrm{mol}^{-1}$ higher with gentisate than with hydroquinone (Szewzyk and Schink 1989). If $\mathrm{Y}_{\mathrm{ATP}}\left[\mathrm{g} \times \mathrm{mol} \mathrm{ATP}^{-1}\right]$ is assumed to be $10 \mathrm{~g} \times \mathrm{mol} \mathrm{ATP}^{-1}$ (Stouthamer 1979) and the free energy for irreversible ATP synthesis to be $70 \mathrm{~kJ} \times$ mol ATP ${ }^{-1}$ (Thauer et al. 1977), strain HQGö1 would gain $25 \mathrm{~kJ}$ per mol more from gentisate than from hydroquinone. This is exactly the energy amount required for hydroquinone carboxylation (Table 4, (3)).

Carboxylation of aromatic compounds has been reported for anaerobic metabolism of e.g. phenol (Lack et al. 1991), aniline (Schnell and Schink 1991), o-cresol (Bisaillon et al. 1991; Rudolphi et al. 1991) or $m$-cresol (Roberts et al. 1990). All these compounds are carboxylated in para-position to a hydroxyl or amino substituent. Hydroquinone carboxylation is the first described orthocarboxylation of a phenolic compound. Unfortunately, no assay has yet been established to detect hydroquinone carboxylase in cell extracts. However, proof of the respective enzyme in the other carboxylation reactions in cell-free extracts is still missing as well.

Formation of benzoate from gentisate requires an elimination of the ortho and the meta hydroxyl group. Reductive eliminations of hydroxyl or amino groups has been observed so far only after activation of the aromatic acid to the respective CoA-ester which results in the destabilization of the mesomeric $\pi$-electron system (Schink et a1. 1992). In cell extracts of strain HQGöl, an acyl-CoA synthetase activity for gentisate and for ben7.oate was detected at high activity. The reactions were linear with time only for a few minutes, due to the presence of an esterase activity $\left(70 \mathrm{nmol} \times \mathrm{min}^{-1} \times \mathrm{mg}\right.$ protein $\left.{ }^{-1}\right)$ in the crude cell extract. Since the maximum concentration of gentisyl-CoA was $0.4-0.45 \mathrm{mM}$, the ester could be prepared in quantitative amounts for further experiments.

With gentisyl-CoA as substrate, a novel enzyme activity was detected in cell-free extracts of strain HQGöl. With reduced viologen derivatives as electron donor, two hydroxyl groups were removed from gentisyl$\mathrm{CoA}$ without intermediate formation of either salicylyl$\mathrm{CoA}$ or 3-hydroxybenzoyl-CoA. With these monohy-
Tahle 4. Approximate Gibbs free cnergy changes of conversion reactions in anacrobic hydroquinone degradation
(1) $3 \mathrm{C}_{6} \mathrm{H}_{4}(\mathrm{OH})_{2}+\mathrm{CO}_{2}+6 \mathrm{H}_{2} \mathrm{O} \rightarrow 6 \mathrm{CH}_{3} \mathrm{COO}^{-}+\mathrm{C}_{6} \mathrm{H}_{5} \mathrm{COO}^{-}+7 \mathrm{H}^{+}$

$\Delta \mathrm{G}^{O^{\prime}}=-102 \mathrm{~kJ}$ (mol hydroquinone) ${ }^{1}$

(2) $3 \mathrm{C}_{6} \mathrm{H}_{3}(\mathrm{OH})_{2} \mathrm{COO}^{-}+3 \mathrm{H}^{+}+6 \mathrm{H}_{2} \mathrm{O}$

$\rightarrow 6 \mathrm{CH}_{3} \mathrm{COO}^{-}+\mathrm{C}_{6} \mathrm{H}_{5} \mathrm{COO}^{-}+7 \mathrm{H}^{+}+2 \mathrm{CO}_{2}$

$\Delta \mathrm{G}^{\mathrm{O}^{*}}=-125 \mathrm{~kJ}$ (mol gentisate) ${ }^{-1}$

(3) $\mathrm{C}_{6} \mathrm{H}_{4}(\mathrm{OH})_{2}+\mathrm{CO}_{2} \rightarrow \mathrm{C}_{6} \mathrm{H}_{3}(\mathrm{OH})_{2} \mathrm{COO}^{-}+\mathrm{H}^{+}$ $\Delta G^{O^{4}}=+24 \mathrm{~kJ}$ (mol hydroquinone) $)^{-1}$

(4) $\mathrm{C}_{6} \mathrm{H}_{3}(\mathrm{OH})_{2} \mathrm{COO}^{-}+2 \mathrm{NADH}+\mathrm{H}^{+} \rightarrow \mathrm{C}_{6} \mathrm{H}_{5} \mathrm{COO}^{-}+2 \mathrm{H}_{2} \mathrm{O}-2 \mathrm{NAD}^{+}$ $\mathrm{AG}^{\mathrm{O}^{3}}=-109 \mathrm{~kJ}$ (mol gentisate) ${ }^{-1}$

Gibos free energies were calculated after Thauer el al. 1977. The $A G f^{\circ}$ value for gentisate $(-578 \mathrm{~kJ}$ per mol) was calculated by comparison with values of the carboxylation of phenol to monohydroxybenzodtes 
droxy-derivatives as substrates, no dehydroxylation activity was observed. These results indicate that both hydroxyl groups are removed simultaneously in one step.

Gentisyl-CoA reductase was irreversibly inactivated by treatment of cell extract with air. Oxygen sensitivity was described also for other eliminating reductase, e.g. 4-hydroxybenzoyl-CoA reductase (Glöckler et al. 1989) and 2-aminobenzoyl-CoA reductase (Lochmeyer et al. 1992).
Reductive elimination has been observed repeatedly in anaerobic degradation of aromatic compounds. This kind of reaction was shown so far with aromatic CoA-esters substituted in para- and ortho-position (Glöckler et al. 1989; Rudolphi et al. 1991; Schnell and Schink 1991; Lochmeyer et al. 1992). Gentisyl-CoA reductase is the first enzyme described which removes hydroxyl groups in ortho and meta position. Studies on 3-hydroxybenzoate degradation allow the conclusion that this single<smiles>Oc1ccc(O)cc1</smiles>

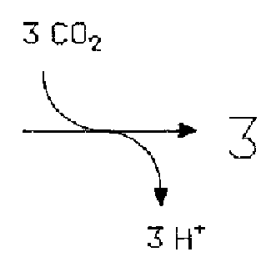<smiles>CC(=O)c1cc(O)ccc1O</smiles>

$3 \mathrm{COASH}$

$$
\text { (OH }
$$<smiles>C1CCC1</smiles>

3 ATP

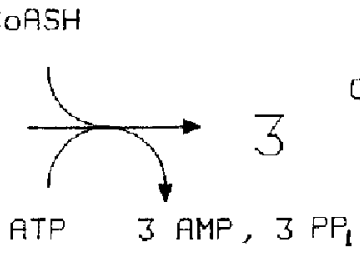<smiles></smiles>

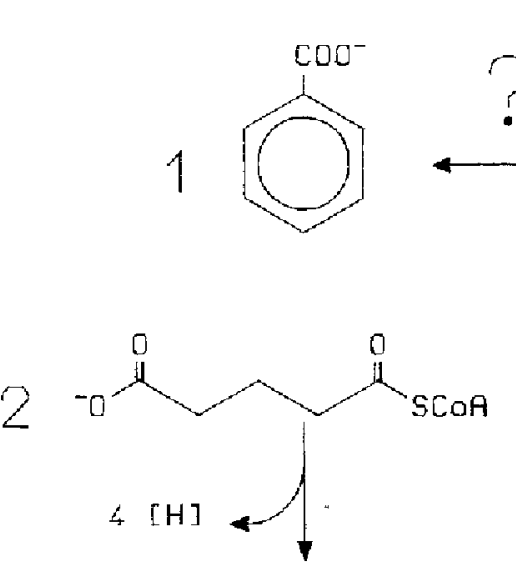<smiles>CC(C(=O)O)C(=CCC(=O)[Hg])C(=O)O</smiles><smiles>CC=CC(=O)[Se]O</smiles><smiles>[Y]C(C)CCCC</smiles><smiles>CC(O)CC(=O)[SeH]</smiles><smiles>CC1CCCCC1C</smiles><smiles>CC(=O)CC(=O)[Se]O</smiles><smiles>CC(C)[C@H](C)O[Mg]</smiles>

Fig. 4. Pathway of anaerobic hydroquinone degradation by the fermenting strain HQGöl as proposed from the results in this study 
meta group is also eliminated by reduction (Heising et al. 1991; Tschech and Schink 1986) but the reductase enzyme involved could not yet be detected in in vitro assays. Elimination of a hydroxyl group in ortho-position has never been described. Lack of reductive elimination of a single ortho- or meta-hydroxyl group, bul simultaneous removal of both substituents in one single reaction indicales that this type of elimination is governed by a basically different reaction mechanism.

In an carlier paper (Tschech and Schink 1986) we speculated that reductive dehydroxylation could contributc to the energy budget of bacteria fermenting hydroxybenzoates. This could also be true for strain HQGö1, based on the free energy changes calculated for the reduction of gentisic acid to benzoic acid (Tablc 4, (4)). Theoretically, more than $1 \mathrm{~mol}$ ATP could be obtained by reducing $1 \mathrm{~mol}$ of gentisate to benzoate with NADH as electron source, which is the physiological electron donor regenerated by $\beta$-oxidation of fatty acids. Up to twelve percent of the gentisyl-CoA reductase activity detected in crude extracts was found in the membrane fraction. This could indicate that this enzyme activity might be associated with an energy-conserving elcetron transport phosphorylation. Unfortunately, a possible contribution of this reaction to the total energy budget is difficult to assess because gentisyl-CoA reductase is the only reaction accepting electrons relased during benzoyl-CoA oxidition, and is therefore indirectly involved in ATP formation via phosphotransacetylase and acetate kinase as well.

Enzymes necessary for the oxidation of benzoyl-CoA to acetate were detected in cell-free extracts. GlutarylCoA dehydrogenase and glutaconyl-CoA decarboxylase are key enzymes involved in anaerobic benzoate degradation, and are present in phototrophic and denitrifying bacteria growing anaerobically with aromatic compounds (Härtel et al. 1993). In cell extracts of strain HQGö1, both enzymes were measured at activities high enough for the calculated in vivo conversion rate of $54 \mathrm{nmol} \times \min ^{-1} \times \mathrm{mg}$ protein ${ }^{-1}$, as well as enzymes of fatty acid $\beta$-oxidation, formate dehydrogenase, and hydrogenase. Phosphotransacetylase and acetale kinase were measured at the in vivo rate or below. We checked for other acetate-forming enzymes such as reversible acetyl-CoA ligase (ADP forming), but without success.

So far an enzyme forming benzoate from benzoyl-CoA could not be detected in cell-free extract. Obviously a benzoyl-CoA-acceptor: $\mathrm{CoA}$ transferase activity was not involved but there was also no indication of a benzoate kinase activity generating ATP via benzoyl phosphate (Dörner and Schink 1991).

On the basis of the results of the present study we propose a pathway of hydroquinone degradation by strain HQGö1 as depicted in Fig. 4. This pathway includes two novel reactions transforming the substrate to benzoyl-CoA: (i) a carboxylase acting in ortho-position to a hydroxy ring substituent, and (ii) a reductive dehydroxylation removing hydroxy substituents in ortho and meta position simultaneously in one reaction step.

Strain HQGö1 was deposited in the Deutsche Sammlung won Mikroorganısmen (DSM), Braunschwelg, Germany under No. 8423
Acknowledgements. The authors are grate[ul to Prof. Dr. W. Buckel, Marburg, for supplyng auxiliary enzymes for the assay of glutaconyl-CoA decarboxylase. Special thanks are due to Dr. P. H. Janssen for reading the manuseript. This work was supported by a grant of the Deutsche Forschungsgemeinschaft.

\section{References}

Bergmeyer HU (ed) (1983) Methods of enzymatic analysis, volumes II-III. Verlag Chemie, Weinheim

Bisaillon JG, Lépine F, Beaudet R. Sylvestre M (1991) Carboxylation of $o$-cresol by an anaerobic consortium under methanogenic conditions. Appl Environ Microbiol 57: 2131-2134

Bradford MM (1976) A rapid and sensitive method for the quantitation of microgram quantities of protein utlizjng the principle of" prolsin-dye binding. Ane1 Biochem 72: 248-254

Brune A, Schink B (1990) Pyrogallol-to-phloroglucinol conversion and other hydroxyl-transfer reactions catalyzed by cell extracts of Pelobacter acidigallici. J Bacteriol 172: 1070-1076

Brune A, Schink B (1992) Phloroglucinol pathway in the strictly anaerobic Pelobacter acidigallici fermentation of trihydroxyberszenes to acetate via triacetic acid. Arch Microbjol 157:417-424

Buckel W (1986) Riotin-dependent decarboxylases as bacterial sodium pumps: purufication and reconstitution of glutaconylCoA decarboxylase from Acidaminococus fermentans. Methods Enzymol 125: 547-558

Conn EE (1964) Enzymology of phenolic biosynthesis. In: Harborne. JB (ed) Biochemistry of phenolic compounds. Academic Press. New York, pp 399-436

Dickert GB, Thawer RK (1978) Carbon monoxide oxidation by Closididum thermotceticum and Closiridium formicoaceticum. $\mathrm{J}$ Bacteriol 136: 597-606

Dörner C, Schink B (1991) Fermentation of mandelate to benzoate and acetate by a homoacetogenic bacterinm. Arch Microbiol 156: 302306

Evans WC, Fuchs G (1988) Anaerobic degradation of aromatic compounds. Annu Rev Microbiol 42: 289-317

Gallert C. Knoll G. Winter J (1991) Anacrobic carboxylation of phenol to benzoate: use of deuterated phenols revealed carboxylation exclusively in the C4-position. Appl Microbiol Biotechnol 136: $124-129$

Geissler JF: Harwood CS, Gibson J (1988) Purification and propertres of benzoate-coenzyme A ligase: a Rhodopseudononas palustris enzyme involved in the anaerobic degradation of benzoate. J Bacteriol 170: 1709-1714

Glöckler R. Tsehech A, Fuchs G (1989) Reductuve dehydrox vlation of 4-hydroxybenzoyl-CoA to benzoyl-CoA in a denitrifying, phenol degrading Psetdomonas species. FEBS Microbiol Lett 251: $237-240$

Härtel U, Eckel E, Kacli J, Fuchs G. Linder D, Buckel W (1993) Purification of glutaryl-CoA dehydrogenase from Psetdomonas sp., ats enzyme involved in the anaerobic degradation of benzoate. Arch Microbol 159: 174-181

Heising S, Brune A, Schink B (1991) Anaerobic degradation of 3-hydroxybenzoate by a newly isolated nitrate-reducing bacterium. FEMS Microbiol Lett 84: 267-272

Kluge C, T'schech A, Fuchs $G$ (1990) Anaerobic metabolism of resorcyclic acids (min-dihydroxybenzoic acids) and resorcinol (1,3-benzenediol) in a fermenting and in a denitrifyng bacterium. Arch Microbiol 155: 68-74

Lack A, Tommasi I, Aresta M, Fuchs G (1991) Catalytic properties of phenol carboxylase. In vitro study of $\mathrm{CO}_{2}: 4$-hydroxybenzoate isolope exchange reaction. Fur J Biochem 197: 473-479

Lochmeyer C, Koch J, Fuchs G (1992) Anactobic degradation of 2-aminobenzoic acid (anthranilic acid) via bonzoyl-cocnzyme $A$ (CoA) and cyclohex-1-encarboxyl-CoA in a denitrifying bacteriam. J Bacteriol 174: 3621-3628

Lynen $F$; Ochoa $S$ (1953) Enzymes of fatty acid metabolism. Biochim Brophys Acta 12: 299-314

Merkel SM, Eberhard AE, Gibson J, Harwood CS (1989) Involve- 
ment of coenzyme $\Lambda$ thioesters in anaerobic metabolism of 4-hydroxybenzoate by Rhodopseudononas palustris. J Bacteriol 171: $1-7$

Moskowitz GJ, Merrick JM (1969) Metabolism of poly- $\beta$-hydroxybutyrate. II. Enzymatic synthesis of D-(-) $\beta$-hydroxybutyryl coenzyme $A$ by an enoyl hydrase from Rhodospirillum rubrum. Biochemistry 8: 2748-2755

Platen H, Schink B (1989) Methanogenic degradation of acetone by an enrichment culture. Arch Microbiol 149: 136-141

Pridham JB (1965) Low molecular weight phenols in higher plants. Annu Rev Plant Physiol 16: 13-36

Roberts DJ, Fedorak PM, Hrudey SE (1990) $\mathrm{CO}_{2}$ incorporation and 4-hydroxy-2-methylbenzoic acid formation during anaerobic metabolism of $m$-cresol by a methanogenic consortium. Appl Environ Microbiol 56: 472-478

Rudolphi A, Tsehech A. Fuchs G (1991) Anaerobic degradation of cresols by denitrifying bacteria. Arch Microbiol 155: 238-248

Schink B, Pfennig N (1982) Fermentation of trihydroxybenzenes by Pelobacter acidigallici gen. nov., sp. nov., a new strictly anaerobic, non spore-forming bacterium. Arch Microbiol 133: $195-201$

Schink B, Brune A, Schnell S (1992) Anaerobic degradation of aromalic compounds. In: Winkelmann $G$ (ed) Microbial degradation of natural products. VCH Verlagsgesellschaft, Weinheim, pp 219-242

Schnell S, Schink B (1991) Anacrobic aniline degradation via reductive deamination of 4-aminobenzoyl-CoA in Desulfobacterium anilini. Arch Microbiol 155: 511-516

Schnell S, Bak F, Pfennig N (1989) Anaerobic degradation of aniline and dihydroxybenzenes by newly isolated sulfate-reducing bacteria and description of Desulfobacterium anilini. Arch Microbiol 152: $556-563$

Simon EJ, Shemin D (1953) The preparation of S-succinyl-CoA. J Am Chem Soc 75:2520

Stams AJM, Kremer DR, Nicolay K, Wenk GH, Hansen TA (1984)
Pathway of propinnate formation in Desulfobulbus propionicus. Arch Microbioi 137: 329-337

Stern JR (1956) Optical properties of acetoacetyl-S-coenzyme A and its metal chelates. J Biol Chem 221: 33-44

Stouthamer AH (1979) The search for correlation between theoretical and experimental growth yields. Int Rev Biochem 21: $1-47$

Szewzyk U, Schink B (1989) Degradation of hydroquinone, gentisate and benzoate by a fermenting bacterium in pure and defined mixed eulture. Arch Microbiol 151: 541-545

Thauer RK, Jungermann K, Decker K (1977) Energy conservation in chemotrophic anaerobic bacteria. Bacteriol Rev 41: 100-180

Tschech A, Fuchs G (1989) Anaerobic degradation of phenol via carboxylation to 4-OH-benzoate: in vitro study of isotope exchange between ${ }^{14} \mathrm{CO}_{2}$ and 4-hydroxybenzoate. Arch Microbiol 152: $594-599$

Tschech A, Pfennig N (1984) Growth yield increase linked to caffeate reduction in Acetobacterium woodit. Arch Microbiol 137: $163-167$

Tschech A, Schink B (1986) Fermentative degradation of monohyw droxybenzoates by defined syntrophic cocultures. Arch Microbiol 145: 396-402

Webster LT, Mieyal JJ, Siddiqui UA (1974) Benzoyl and hydroxybenzoyl esters of coenzyme A. Ultraviolet characterization and reaction mechanisms. J Biol Chem 249: 2641-2645

Widdel F, Pfennig N (1981) Studes on dissimilatory sulfate-reducing bacteria that decompose fatty acids. I. Isolation of new sulfate-reducing bacteria enriched with acetate from saline environments. Description of Desulfobacter posigatei gen. nov., sp. nov. Atch Microbiol 129: $395-400$

Widdel F, Kohring GW, Mayer F (1983) Studies on dissimilatory sullate-reducing bacteria that decompose fatty acids. III: Characterization of the filamentous gliding Desulfonema imicola gen. nov., sp, nov., and Destlfonemo magmum sp. nov. Arch Microbiol $134: 286-294$ 